made and admirably adapted to their peculiar use. Ornamentation was confined, in the vast majority of cases, to the natural markings of the mineral, and not derived from any carving as is so marked a characteristic of the pipes of the mound-builders. Fig. 6 represents a perfect specimen of such plain pipe bowls as I have described. There is no line, straight, curved, or zigzag upon it. The red man who made this specimen had utility solely in view ; unless the choice of mineral was considered, as giving beauty to the finished pipe. The material of the specimen fioured is a pale green slaty rock, veined with black. The variation in shape of such pipe bowls is of course considerable; and supposing each individual to have made his own pipe, the shape was in each case decided by the maker's fancy solely. As in the case of arrow. points, of which a score of patterns occur, so with pipe bowls. One will scarcely find two precisely alike; yet the "family likeness" is very strongly marked.

There does occur, however, a second form of smoking pipe, but much more sparingly than the preceding, differing greatly, both in size and shape. While the two patterns occasionally approach in general outline, they do not do so sufficiently to warrant our considering the one to pass into the other form.

This variety of pipe, of which Fig. 7 is an example, is well known as the calumet or "peace-pipe." The bowl

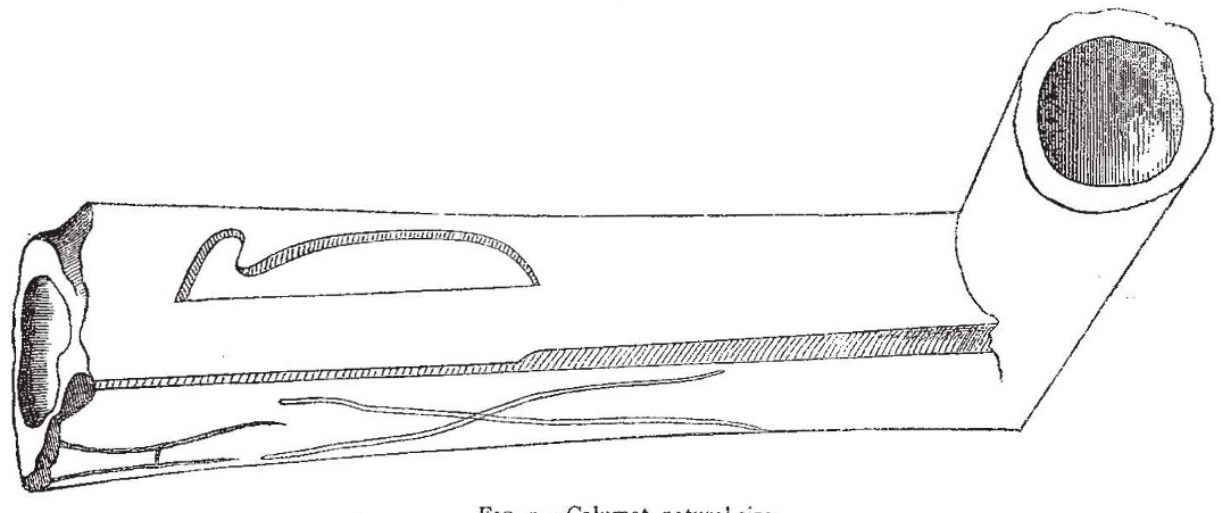

FIG. 7. -Calumet, natural size.

in this case, as a rule, is much smaller, and the labour of the maker has been expended upon the stem-like base, which in every specimen I have seen has been quite elaborately ornamented. The specimen figured is not as much carved as many, but being quite perfect, is represented in preference to fragments of others.

I believe no specimens of " animal pipes," such as are found in the Mississippi valley, have been found in New Jersey, which fact is interesting, as there is much reason for believing that when the mound-builders occupied the western valleys the red man was already occupying the Atlantic coast; and doubtless some trading was carried on between the two peoples. Therefore, it would be natural to expect that such pipes should occur among our Indian relics; or at least that there was sufficient knowledge concerning them to suggest to the coast Indians the idea of imitating them; but there is no trace of such imitation I believe. It is their smoking pipes alone, of all their productions in the flint-chipping art, that are dissimilar.

Through the writings of the earlier missionaries we learn of the peculiar uses and significance of these calumets, which formed so prominent a feature on all important occasions; but whether they were introduced by some other race with whom the red man came in contact, or originated de novo, it is impossible to determine; but it is quite certain that the specimens so far brought to light do not enable us to trace the evolution of the calumet from the simpler form of pipe.

Trenton, N.J., U.S.A., May 6 Chas. C. AвBOtT

\section{NEW METEOROLOGICAL LABORATORIES AT MONTSOURIS}

M MARIÉ DAVY, Director of Montsouris ObservaNI. tory, has organised, partly at the expense of the French Government, partly at the expense of the City of Paris, a chemical and microscopical laboratory for the analysis of all the matters in suspension in the air of Paris, both quantitatively and qualitatively. A certain quantity of air is constantly aspired by an aspirator in continued operation. The ozone acting on iodide of potassium and starch liberates iodine. The quantity of nzone liberated is measured by a titrated solution of arsenite of sodium. The matters in suspension are collected on a glass plate, and the crop is placed under the cbject-glass of a powerful microscope magnifying $\mathrm{I}, \infty 00$ times. The principal forms are drawn and plates are executed and published monthly in the Transactions of the establishment. The analysis of rain-water is conducted on the same principles, and the results of chemical analysis are calculated and compared with the wind and other atmospheric circumstances.

We are indebted to $M$. Marie Davy for the principal results of the month of February, the first period for which the whole system has been put into complete operation.

The electrical department has been fitted up, after a preliminary trial, and has been in working order for some time. In orcier better to illustrate the importance of these researches we take the liberty of altering the figures in order to give the results in round numbers for the whole area of Paris within the fortifications. The surface is about $80,000,000$ square metres. In February 1876 the quantity of atmospheric water was $4,500,000$ cubic metres. This is about double the average, but in some years on record the quantity was even larger, in 1776 a century ago, it was more than $6,500,000$ cubic metres. In taking as an average the analyses of rain-water at Montsouris, the $4,500,000$ cubic metres contained 4,700 kilogrammes of nitric acid and 10,700 kilogrammes of ammonia. This mass of nitric acid is supposed to have been produced by electrical reactions in the atmosphere, and ammonia only partly, as Montsouris is in the southern part of the city, close to the fortifications.

The 4,500,000 cubic metres of rain water were also proved to contain 172,000 kilogrammes of organic matter, and 88,400 kilogrammes of metallic salts or products. A number of organic matters have been found 
to be composed of spores, parts of animalculæ, and even living infusoriæ. Amongst the metallic salts we must mention particles of meteoric iron, evidently of cosmic origin. It is contemplated by the city of Paris to establish similar observations in several parts of the city, and the careful comparison of these analyses will prove invaluable for establishing a number of most interesting facts having a bearing on the welfare of inhabitants, as well as on the elucialation of important scientific problems.

It is also contemplated to make use of aëronautical ascents to test the air at any altitude accessible to a balloon with horizontal glass plates covered with glycerine. The moisture of the clouds is to be condensed on glass tubes which will be refrigerated.

The ozone testing and measuring has produced also startling facts. Although the quantity of ozone is very minute, amounting to only a few milligrams per $\mathrm{I}, 000$ cubic metres, it has been proved that on Feb. 27 , the day of the ozone maximum, a quantity of 900 kilog. was floating over Paris, if we suppose that the quantity was the same as at Montsouris in the whole stream of air passing above up to the altitude of 1,000 metres.

These results are only a sample of those which may be expected from the constant application of the magnificent system which is now brought into operation for the first time, and of which it will be possible to say, Vircs acquirit eundo.

W. DE FONVIELLE

\section{NOTES}

THE following are the arrangements for the Free Lectures in connection with the Loan Collection of Scientific Apparatus for the next few weeks. The lecture hour is eight P.M. Saturday, June $17, \mathrm{Mr}$. W. H. Preece on Telegraphic Instruments; Monday, June 19, Mr. Kempe on the Application of Linkages to Machinery; Saturday, June 24, Capt. Abney, F.R.S., on Photographic Printing Processes ; Monday, June 26, Dr. Schuster on Ampère's and Faraday's Instruments; Saturday, July I, Mr. W. C. Roberts, F.R.S., Graham's Apparatus and what he did with it; Monday, July 3, The Right Hon.Dr. Lyon Playfair, C.B., F.R.S., Otto von Guericke's and Black's Instruments ; Saturday, July 8 , Dr. Gladstone on the Instruments lent by the Royal Institution.

ON the rst inst. the Society of Arts of Geneva celebrated the first centenary of its existence. Founded in 1776 by H. B. De Saussure and some of his friends, it has continued ever since to render real service to Switzerland in the departments of Arts, Industry, Commerce, and Agriculture. Without having any direct connection with science, it has always, however, been associated with it, and all the scientific men of Geneva have from time to time taken a share in its proceedings ; the Pictets, De Candolles, De la Rives, and other well-known names, have at various times been presidents. A prize founded by Aug. De la Rive, to be awarded to the discovery most useful to Genevese industry, is intrusted to the care of the Society. In order worthily to celebrate the centenary, the Society had announced various competitions in the different branches with which it is connecter, and which appealed to all manufacturers of horological instruments. The nature and terms of this competition we announced last October (vol. xii., p. 525). It was an international competition in chronometry, in which there was a large number of competitors, and of which the results have been now made known. A Prize of Honour was awarded to $M$. Ulysse Nardin, of Locle, Neuchâtel; six equal First Prizes were awarded to M. H. R. Ekegrin, of Geneva, Messrs. Parkinson and Frodsham, of London, Messrs. Badollet and Co., Geneva, Predard et Fils, Geneva, M. Ed. Perregaux, of Locle, and M. Fritz Piguet, of Geneva; other awards were likewise made. After the general meeting and the distribution of prizes, a banquet was held, at which about four hundred members of the
Society were present; this was followed by a conversazione on the terrace of M. Th. De Saussure, grandson of the celebrated naturalist, the founder of the Society, on the very pl ace where the first meeting was held a century ago.

AT the meeting of the Royal Geographical Society on Monday, Sir Rutherford Alcock, the new president, in the chair, a paper by Mr. E. D. Young, R.N., was read, on a journey to the northern end of Lake Nyassa. The cruise round Lake Nyassa had occupied a montb, and the area was much larger than Dr. Livingstone thought, the north end extending to $9^{\prime} 20 \mathrm{~S}$. lat. In most parts it was very deep, and in several places no bottom could be found with 100 fathoms of line. A range of mountains nearly Ioo miles in length, extended above the lake, some reaching an elevation of 10,000 or 12,000 feet. There were also numerous rivers running into the lake, but none navigable for any distance. At some parts there were numbers of villages built on piles in the lake; many people in other parts living on barren rocks. Mr. Young added that he intended to be back to England in a few months, and would in the meanwhile make a more perfect survey of the lake and give the results to the Geographical Society on his return. A paper on "The Valley of the Tibagy, in Brazil," by Mr. T. B. Wither, C. E., was also read. The author of the paper was engaged in conjunction with others, in August, I87I, in exploring that section of the Ivahy Valley which lies between Colonia Theresa and the Corredeira de Ferro, or "Iron Rapid."

THE University of Oxford proposes to confer the degree of D.C.L. upon the following, among others :--Prof. W. H. Miller, F.R.S., Prof. J. Clerk Maxwell, F.R.S., Dr, Samuel Birch, and Lieut. V, L. Cameron.

THE Oxford University Bill was read a second time in the House of Commons on Monday. In the debate which followed there was nothing worthy of comment.

THE annual conversazione of the Society of Arts will be held at South Kensington Museum on Friday, the 23rd inst.

IN a recent issue of the Italian medical journal L'Imparziale laments that the unjust and ridiculous accusations of a number of strangers resident in Florence and of an exceedingly small minority of the inhabitants should have induced Prof. Schiff to accept the chair which has been offered to him at Geneva. The loss to physiology in Italy will be so great that, according to a communication in the Daily News, the Bersagliere believes that the Minister of Public Instruction will use every endeavour to make the illustrious physiologist withdraw his resignation.

EXCELLENT accounts have been received from the German North Asiatic Expedition, which ${ }^{\circ}$ has arrived as far as Semipalatinsk, in Siberia, and has obtained living specimens of the large Argali sheep (Ovis ammon) of Linnæus.

THE veteran ornithologist, Dr. Hartlaub, has in preparation a new work upon the Ornithology of Madagascar and the adja. cent islands. Since Dr. Hartlaub's original memoir on this subject was published in $186 \mathrm{r}$, since which time Pollen, Van Dan, Crossley, Grandidier, and others, have done much to increase our knowledge of the avifauna of Madagascar.

We hear from Sidney that the sum of $800 \%$. had been raised towards Signor D'Albertis' expedition up the Fly River, New Guinea ; and that he was intending to start from that city on the rgth of April with the steam-launch loaned to him by the Government of New South Wales.

We regret to hear that the strife at Sidney about the dismissal of Mr. Krefft from the post of Curator and Secretary of the Australian Museum is not over. The subject came before the Legislative Assembly on the 6th of April, and provoked an 